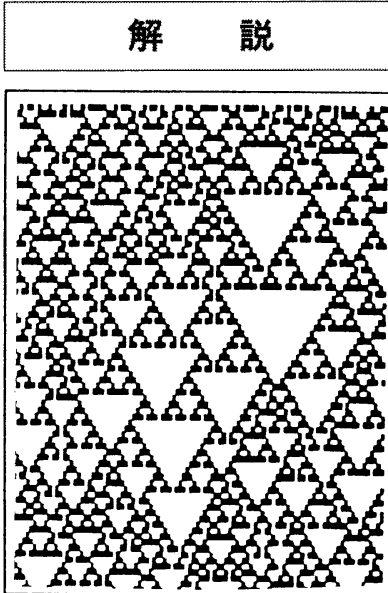

\title{
GaAs MMICの実装技術の現状
}

The Current Technology of GaAs MMIC Packaging

青木 芳雄*

\section{1.はじめに}

携带電話やPHSなどの準マイクロ波を使った移動体 通信は今たいへんなブームになっている。DBSやCSデ イジタル多チャネル放送などマイクロ波を使った放送シ ステムは，今年から新規システムが立ち上がることを卜 リガーにして，これまた急速な普及が予想される。さら にミリ波レーダなど新規なシステムが構想されており， 今まで工業通信用途でしか利用されていなかったミリ波 の民生応用がはじまることになる。

マイクロ波帯の信号を扱う上で, GaAs半導体はなく てはならないものである。さらに，機器の小型化に応之 るためにGaAsチップ上にマイクロ波回路を集積化した MMIC (Monolithic Microwave Integrated Circuit) が広く使われるようになってきている。MMICチップ の開発とともに，それを実装するパッケージングも重要 な技術開発アイテムである。

移動体通信端末機に使われるGaAs MMICのパッケ ージングについては，すでにいくつかのレビューがある ので，ここでは簡単に高周波用途のための技術に絞って 説明する。さらに，比較的周波数の高いX-, $\mathrm{Ku}^{-}$带 $\mathrm{BS}$ /CS コンバー夕用MMICの一次実装技術, ミリ波MMIC の実装技術をとり上げて，現状技術を紹介する。技術的 ポイントとしては，高周波信号のフィールドスルー構造 とMMICチップの安定動作技術に注目する。

\section{2. 移動体通信用MMICの実装技術}

携帯電話などの移動体通信では，準マイクロ波信号処 理にGaAs MMICが広く使われている。現在使われて いるMMICのパッケージは，Si（シリコン）デバイスで 用いられているプラスティックモールドである。これら モールドの外形ないしリードフレームは高周波を意識し て設計されたものではないため，Siデバイスにとっての 高周波である準マイクロ波領域においては，パッケージ としては特性は必ずしもよくない。低コストと小型化の 強い要求から，特性に不満を残しながらもモールド・パ ッケージを使っているのが実際である。

しかしながら，GaAsデバイスはSiデバイスに比べ利 得が高いため, 既存のモールドではどうしても動作させ られない場合がある。こうした例として，GaAs MMIC 用に新たに開発したモールド・パッケージを紹介する。 搭載されているMMICは，PHS用電力増幅である。こ れは, 1.9GHzにアップコンバートされた信号を無線と して送信するための信号増幅を行うMMICである。

主な特性は, $1.9 \mathrm{GHz}$ に打いて出力電力 $21 \mathrm{dBm}$, 電力 利得 $42 \mathrm{~dB}$, 隣接チャネル電力漏洩比 $-60 \mathrm{~dB}(21 \mathrm{dBm}$ 出 力時), 直流バイアス $3.3 \mathrm{~V}-160 \mathrm{~mA}$ (いずれも標準值) である。1. $9 \mathrm{GHz}$ という周波数で利得 $42 \mathrm{~dB} の$ 増幅動作を 安定して行い, $100 \mathrm{~mW}$ 以上の出力電力を確保するために は，パッケージの高周波接地がとれていることが極めて 必要となる。中のMMICは 4 段のFET増幅器で, 最終 段のFETの入力インピーダンスは $1.9 \mathrm{GHz}$ では $10 \Omega$ 以下

* Yoshio Aoki

富士通侏化合物半導体事業部 第二技術部/Compound Semiconductor Group, Fujitsu Limited. 

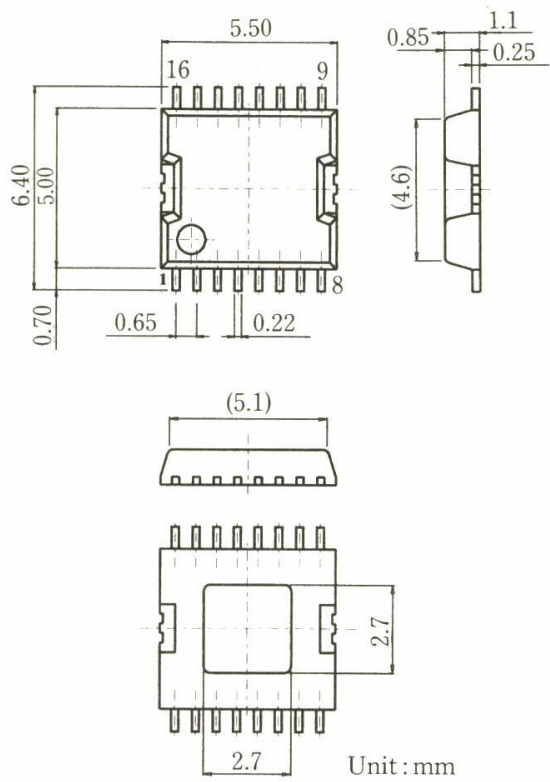

に小さくなる。仮にモールド・パッケージのリードイン ダクタンスを0.1nHと見積もっても, $1.9 \mathrm{GHz}$ でのリア クタンスは $1 \Omega$ 以上になる。さらにボンディングワイヤ のインダクタンスが加わるので，FETのインピーダン スに対し充分な接地（接地＝0 $\Omega$ ）とはいえなくなる このためMMICの接地となる回路部分がリアクタンス 分フローティングされてしまい, 帰還がかかったり, 回

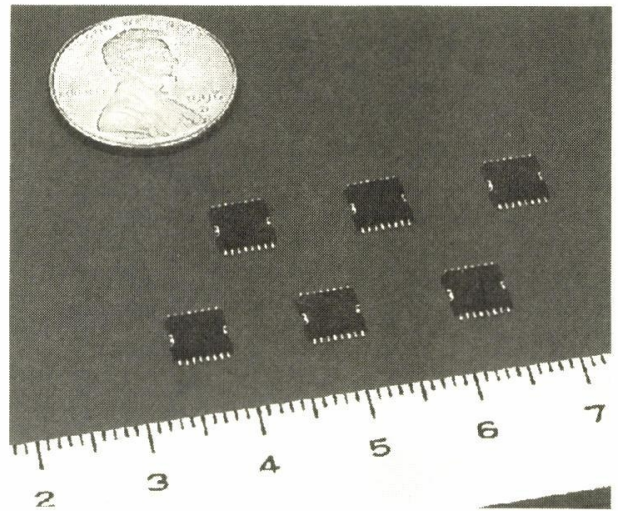

Fig. 1 Outline drawing and outer view of MMIC amplifier for PHS.

路の安定性を低下させたりする。

高周波接地はパッケージの重要な要件であり，ここで 説明するパッケージでは，このための工夫がなされてい る。Fig.1にはこのパッケージの外形図扔よび外観を示 す。外形は通常のSSOP-16 同一になっているが, 実 装面に接地用金属板を露出させた構造となっている。以 前より，パワートランジスタの放熱構造として，こうし たヒートシンクがとられているが，ここではヒートシン クとしてよりも高周波接地の役割を果たしている。

モールド・パッケージの場合, MMICのボンディン グパッドからリードのパッドまでの距離は意外に長く,

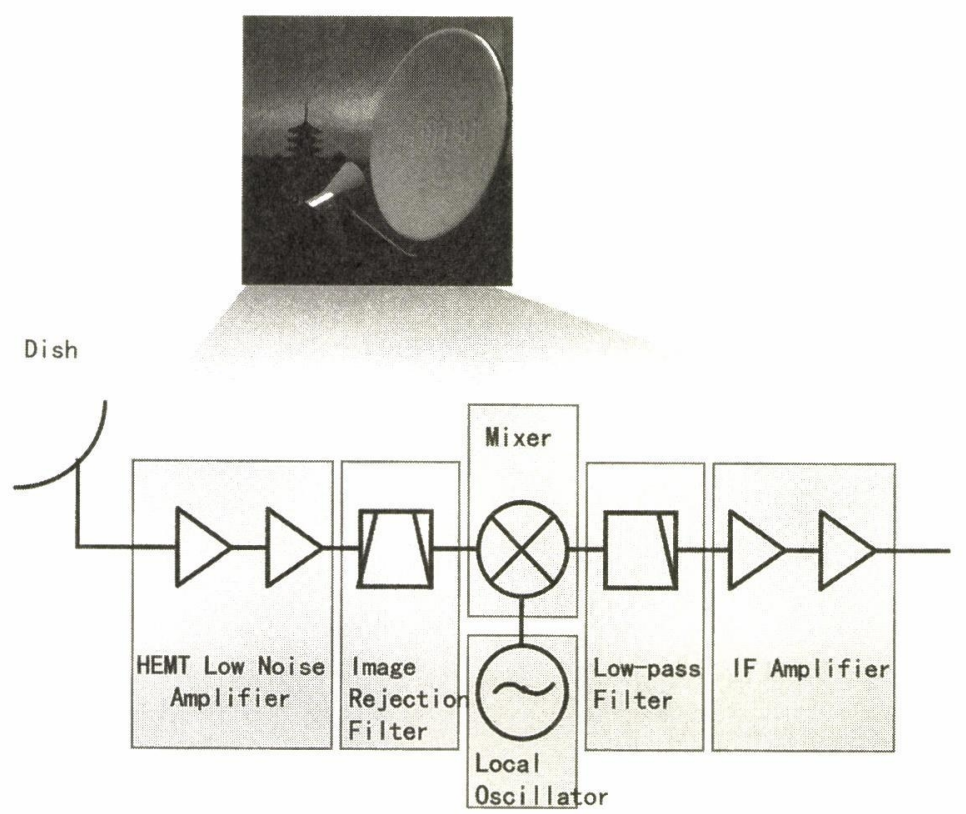

Fig. 2 Functional block diagram of DBS downconverter.

Vol. 13, No. 3 


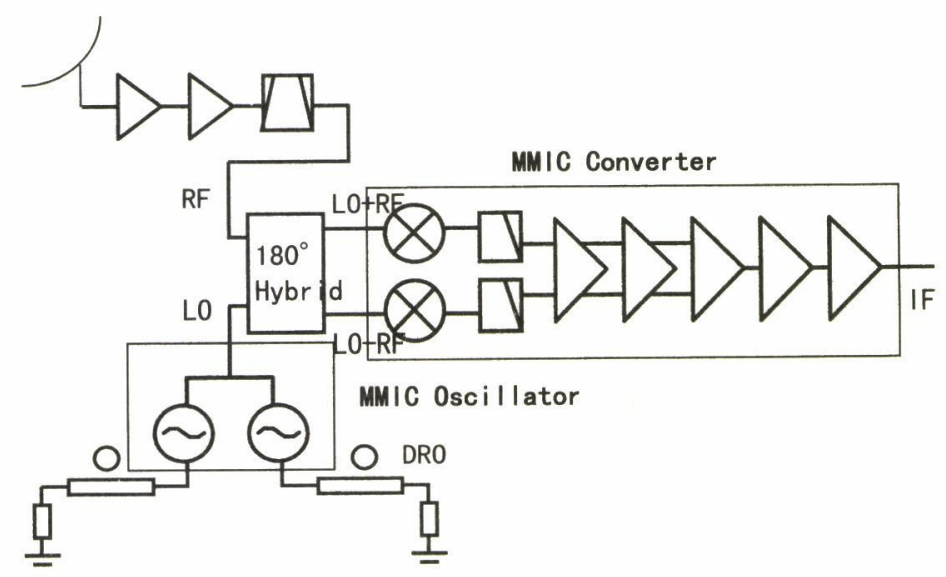

Fig. 3 Block diagram of MMIC converter.

時に $1.0 \mathrm{~mm}$ 以上にもなる。MMICチップ搭載金属部よ り接地をとるこの構造では, 接地用ワイヤはチップ搭載 ステージに対して打ち落とすので，ワイヤ長さはせいぜ いチップ厚みの1.5 2.0倍程度ですむ。複数本のワイヤ を打つことで，接地インダクタンスは $0.1 \mathrm{nH}$ 以下に抑え ることができ，MMICは安定に動作する。

また増幅器MMICの利得が $42 \mathrm{~dB}$ もあるので, 大力と 出力の端子間アイソレーションもそれ以上の $50 \mathrm{~dB}$ 以上 は必要となる。このパッケージでは, 実装時に接地金属

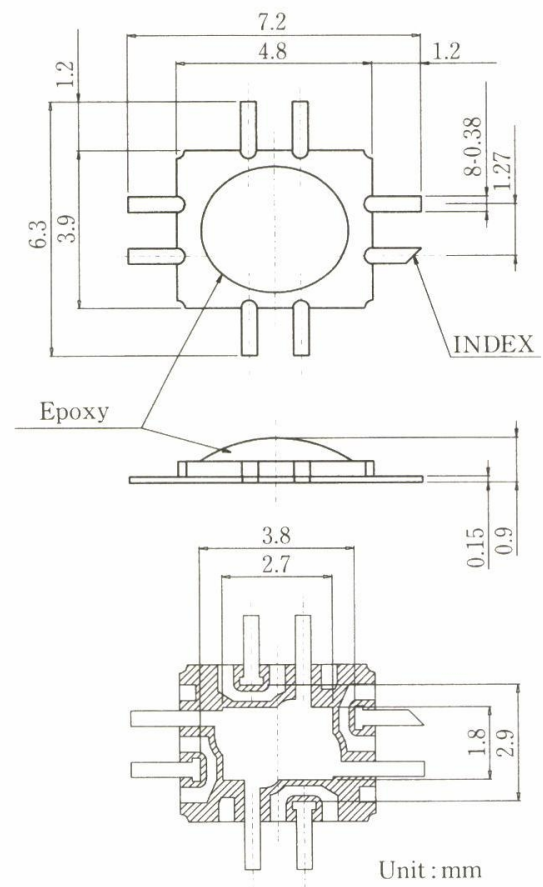

板の接地をとれば，接地金属板を挟む 2 つのリード間の アイソレーションは $1.9 \mathrm{GHz} て ゙ 50 \mathrm{~dB}$ 以上確保できる。

\section{X帯コンバータMMICの実装技術}

衛星放送については今さら説明をするまでもない。 HEMTを有名にしたのもコンバータであろう。さてBS コンバータの機能ブロックダイアグラムは, Fig.2のよ うなものが一般的である。低雑音増幅器にはディスクリ 一トHEMTが使われる。その後段にあるミクサ以降の 部分には，MMICが使われるようになってきている。 ここでは，コンバータMMICと発振器MMICを例にと り上げてパッケージングを説明する。

X带ダウンコンバータMMICは, Fig.3に示すように， シングルバランス型ミクサとIFアンプを1つにした MMICである。衛星から送られてくる電波は, $12 \mathrm{GHz}$ どの周波数である。これは一般家庭で扱う最も高い周波 数である。ミクサ部は, 局所発振器で発生する $10.5 \mathrm{GHz}$ ほどの基準信号とミックスして差の周波数である 1.5 GHzほどのIF信号に変換する。IF信号はIFアンプによ

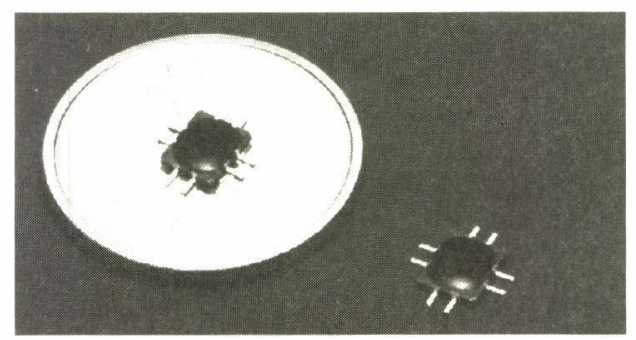

Fig. 4 Outline drawing and outer view of MMIC converter. 
り増幅され，BSチュー十に送られる。MMIC全体の総 合変換利得は $35 \mathrm{~dB}$ (Typ.) である。

$10 \mathrm{GHz}$ を超える高周波信号を扱うMMICを, 家庭用 に廉価に製造する必要から,このMMICでは, チップ のほかパッケージにも以下のような要求が課せられる。

(1) $12 \mathrm{GHz}$ の信号を低損失・低反射に通過させるフィー ドスルーとすること。

(2)MMIC安定動作のための高周波での接地をとれる構 造となっていること。

(3)MMICの利得以上のパッケージ端子間アイソレーシ ヨンがとれること。

(4)表面実装対応であること。

(5)低コストであること。

こうした要求から開発されたパッケージの構造をFig. 4 に示す。

このパッケージは, 枠状のセラミックにリードフレー ムを接着させただけの単純な構造を持つ表面実装タイプ である。MMICチップ搭載部はリード部分と同じフレ 一ムで作られる。セラミックは板状ではなく枠状として, 中にMMICを落とし入れる構造である。このためMMIC 表面のパッドよりパッケージの端子部への距離が短く, ワイヤによるインダクタンスを小さく抑えている。

接地用の端子は広いメタライズパターンになっており, セラミック枠のキャビティの内側の側面のメタライズを 通して, MMICチップ搭載部に通じる。表面実装構造 であるため，パッケージ裏面の接地を容易にとることが でき，かつパッケージ内での接地端子よりの経路が最短 になっているため, 先のPHS用MMICと同様に, 高周 波での接地は立分である。

また, 機能端子と接地端子を交互に配置しており, 機

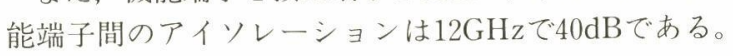

セラミックベースのメタライズパターンは, 軸対称性を 破って,2回の回転対称性を持たせている。これにより, セラミックベース作製時のメタライズパターンをすべて 連結させることができ，コストダウンが可能となってい る。

信号のフィードスルー部は, チップ近傍でコプレーナ 線路となるように設計されている。全体のパターンは, リード部が実装基板上でマイクロストリップ線路を構成 することを想定して，マイクロストリップ線路からコプ レー十線路への変換として皮射と損失を抑えた設計をし ている。

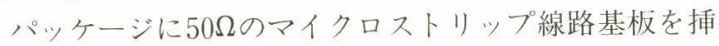
入して測定した結果から, フィードスル一部の挿入損失 は0.2dB（@12GHz）, 反射損はー20dB（@12GHz）以 下に抑えられている。

Vol.13, No. 3
MMICチップはキャビティ内に落としこまれるよう にして金属ベースにロー付けされ，ワイヤボンディング されたあと、樹脂材により保護される。マイクロ波領域 では, 組立時のワイヤ長さ, 封止樹脂特性がMMIC全 体の特性に大きく影響する。したがって, MMIC回路 設計時に既に実装状態を考慮して，ワイヤのインダクタ ンス成分, パッケージ容量, 封止樹脂材による寄生容量 成分を折り込んでシミュレーションを行う。さらには千 ップ搭載位置やワイヤ長さバラツキによるインダクタン スのバラツキを許容できるだけの設計余裕度をとってい る。

こうしたことは, コンバータ用発振器MMICについ てもあてはまる。このMMICは, EIAJでSC-47の外形 コードをもつミニ 6 ピンの樹脂モールド・パッケージに 入れられている。先にも述べたが, モールド・パッケー ジはマイクロ波デバイスのために設計された訳ではない。 したがって，マイクロ波で使用するとMMICチップの もつ特性を引き出すことが難しい。

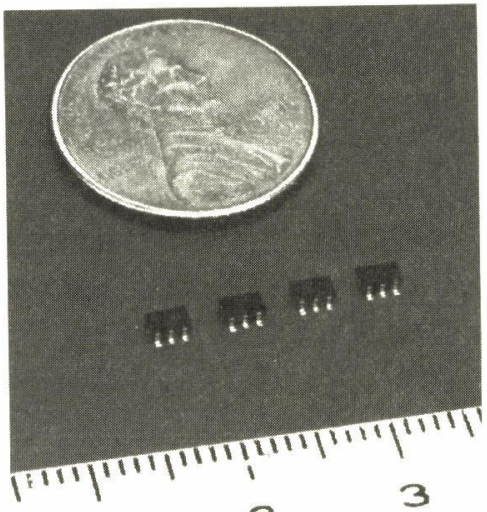

1

2

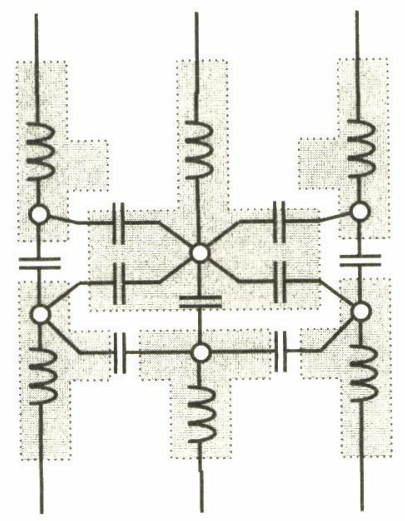

Fig. 5 Outer view of MMIC oscillator and equivalent circuit of its package. 

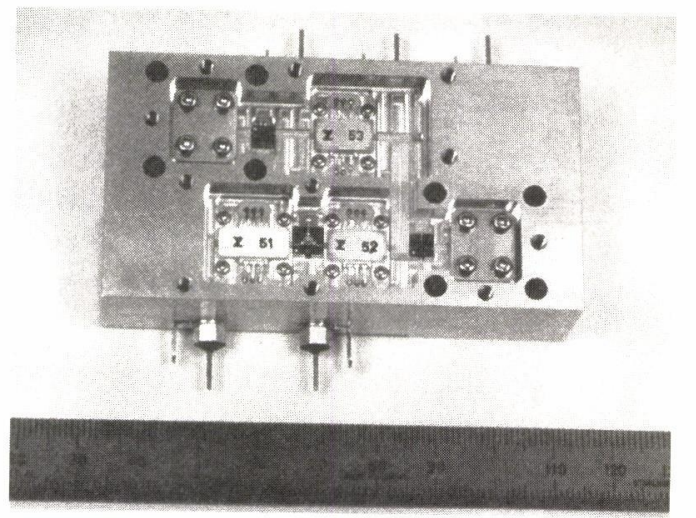

Fig. 6 Inner view of millimeter-wave radar front-end.

Fig.5にはこのパッケージの外観と等洒回路例を示し てある（パッケージ・リードフレームの回路はフレーム の形状に依存するので，ここに示したものは一例と考え ていただきたい)。MMICチップの設計では，パッケー ジの寄生効果を考慮することはとりわけ重要である。設 計に際しては, まずパッケージの等価回路と各定数を把 握する。このMMICは誘電体共振型発振器であり, FET を発振素子としている。発振周波数は, 誘電体共振器側 の反射利得を最大とする周波数として決まる。反射利得 は接地のインダクタンスとキャパシタンスに依存する。 すなわち、これらを正確に把握してMMICの回路設計 にのぞむ必要がある。発振器といえども高周波接地が恵 いと, 自己発振を起こしてしまう。MMIC全体の設計 では,パッケージ, チップ, アセンブリ（ワイヤなど）, 2 次実装環境を全て取り込んだ設計を行っている。

このように低コストを要求されるMMICでは，新規 にパッケージを開発する必要があるのか否かを見極める ことも設計者の重要な選択ポイントである。既存のモ一 ルド・パッケージを使用することを選択する場合には， 寄生容量とインダクタンスなどを正確に見積もり，使用 可否を検討する。ここでとり上げたように，既存のパッ ケージであっても設計によってX帯で使用することもで きる。これも広義の実装技術と言えよう。

\section{4. ミリ波MMIC}

ミリ波MMICのパッケージングはまだオープンプロ ブレムである。ここでは, 1つの提案としての $60 \mathrm{GHz}$ 用 パッケージと, 今後の動问を述べることにする。

日本では, 60GHz带がレーダ，通信などを始めとする 新しいシステム用に割り当てられている。MMIC千ッ

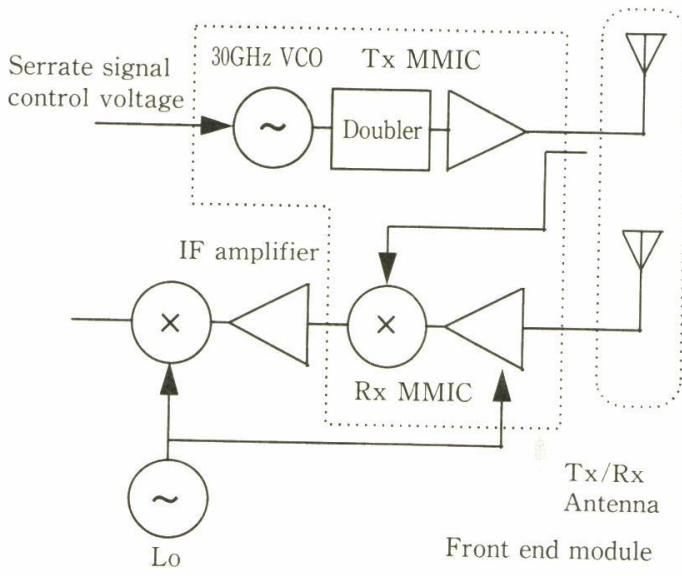

Fig. 7 Block diagram of $60 \mathrm{GHz}$ front end module.

プの開発と、それを搭載したシステムの報告が最近の数 年に多数なされている。代表的なものは，文献 1) を参 照されたい。特に自動車に搭載されるレーダセンサは, 車の安全性向上に役立つシステムとして期待される用途 である。レーダの試作開発も報告されており ${ }^{2)}$ ，実用化 に向けて動き出している。

ミリ波MMICは, デバイスの性能の限界との戦いで ある。たとえば, アクティブデバイスとして $\mathrm{f}_{\max }$ （最大 発振周波数) $=120 \mathrm{GHz}$ のFETを使用するとしよj。 $\mathrm{f}_{\max }$ とは, そのFETを使って理想的な整合回路を付けた増 幅器を作った時に利得が $0 \mathrm{~dB}$ となる周波数である。 $\mathrm{f}_{\text {max }}$ 付近の周波数では，利得は周波数に対し，おおむね $6 \mathrm{~dB}$ Oct. の変化をする。つまり，周波数が倍 (半分) に なると利得は $6 \mathrm{~dB}$ 減少 (増加) する。 $\mathrm{f}_{\max }=120 \mathrm{GHz}$ の FETを使ったMMICでは, $60 \mathrm{GHz}$ で 1 段当たり最大 6 $\mathrm{dB}$ の利得を得ることができる。実際には回路の損失や 増幅器の带域幅を考慮すると, せいぜい $4 \sim 5 \mathrm{~dB}$ 程度 が得られる最大利得と言える。こうなるとパッケージの 損失やインピーダンスの不整合をいかに抑えるかが重要 となる。

ミリ波帯のMMIC搭載方法として一般的に使われて いるのは，チップキャリアである。これはMMICとそ の周囲の伝送線路パターンをもつ誘電体基板とを金属べ 一ス板に並べたものである。MMIC自体は剝き出しの 状態であるため， R\&Dとしては使えるが実用とはなら ない。特に車載用途を考之ると気密封止は必須である。 ミリ波気密封止パッケージでは，ミリ波の信号フィード スルー部分の構造がポイントとなる。

Fig.6には文献 2) で紹介されているミリ波レーダフ ロントエンドの内部写真を示す。内部にはFig. 7に示す 


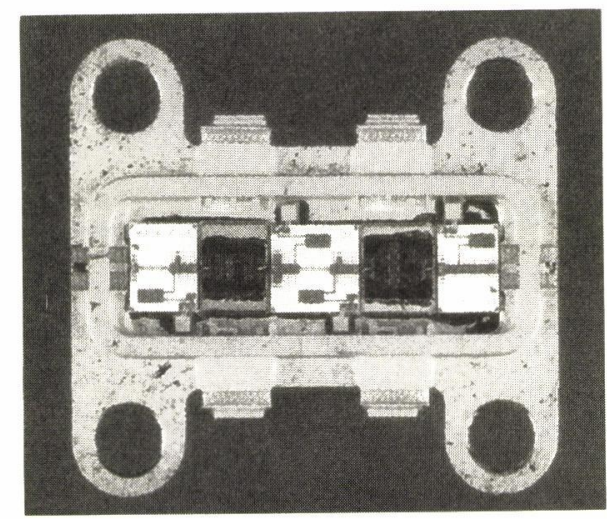

Fig. 8 Inner view of $38 \mathrm{GHz}$-band MMIC amplifier.

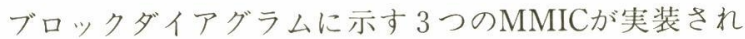
ている。ここで使われているパッケージは, 文献 3 ) で 報告されている衛星搭載用 $38 \mathrm{GHz}$ 带増幅器用のミリ波 パッケージ (Fig. 8) をベースにして，使用周波数を60 GHzに上げるよう設計されたものである。メタルーセラ ミックの気密パッケージで，全体は金属で成形され，信 号とバイアスのフィードスルー部分にセラミック片が使 われている。金属べースであるためにミリ波でも接地は 問題ない。フィードスル一部のメタライズパターンはマ イクロストリップラインーサスペンデッドラインとして, 電磁界シミュレーションによって詳細設計している。フ イードスルー部の $60 \mathrm{GHz}$ での損失は $0.3 \mathrm{~dB}$, リターンロ スはー20dBを確保している。

内部にキャビティ空間をもつパッケージでは，共振を 抑える構造とすることも重要である。パッケージの共振 についてのモードの説明は文献 4) にていねいな説明が あるので参照されたい。たとえば $60 \mathrm{GHz} て ゙$ 共振が起こ らないようにするには，キャビティを $2.5 \mathrm{~mm}$ 以下の辺 の長さで構成する必要があるが, これはMMICのサイ ズと同程度であり，実際には共振の全く起こらないキャ ビティを実現することは難しい。文献 5 ) でもとり上げ られているが,こうしたキャビティ共振を抑えるには， キャビティ内部に電波吸収体を配置するなどの方法が採 られることが多い。

ミリ波のパッケージングの技術については, 文献 5 ), 6 ）に技術的問題点とそれを解決する技術が説明されて おり，詳細はこれらの文献を参照されたい。マイクロ波 と同じくミリ波においても低コストのパッケージや実装
技術，試験技術が求められている。またレーダ用途など 信頼性も必要である。MMICチップ開発の技術的展望 が開けた現段階では, 実装と試験に関する技術開発が大 きなテーマである。今後のパッケージの開発の方向も明 らかではないが，個人的には，電磁界結合などの技術に よる非接触フィードスルー構造とチップサイズキャビテ イやフリップチップなどによる共振防止構造が有望に思 われる。

\section{5.まとめ}

マイクロ波・ミリ波MMICのパッケージの現状をい くつかの例を中心に説明した。MMICは基本的には民 生市場で応用されるデバイスといえる。したがって，パ ッケージも低コストでありながらマイクロ波でも使用で きる高性能が求められている。このため, 既存のアセン ブリ技術を使いながらも, 高周波接地や高周波フィード のための構造を設けたり，既存のパッケージであっても， 回路設計時にパッケージのモデルを取り入れることでマ イクロ波で使用できるようにしている。

ミリ波のパッケージは, ミリ波特有の共振などの問題 解決が今後の開発の大きなテーマとして残されている。

\section{参 考 文 献}

1) 滝本幸男：「ミリ波利用と応用システムの展望」, 電気学会 研究会資料, 電子デバイス研究会 EDD-95-45 (1995)

2) N. Okubo : "Millimeter-Wave Automotive Radar", MWE'96 Microwave Workshop Digest, WS13-4 (1996)

3 ) 永友和雄, 小池章一, 大久保尚史, 高橋英德, 五十嵐 勉, 中谷哲二, 志坦雅文：「38GHz帯MMIC堌幅器」, 1990年電子 情報通信学会春季全国大会 SC- 2-1 (1990)

4）宮川文雄, 宮本隆春, 永田欣司：「ビア工法を用いた伝送 線路の高周波特性」, SHM会誌, Vol.12, No.3 (1996)

5 ）石塚文則：「超高速／高周波実装技術の現状と課題」, SHM 特別セミナー「次世代寒装技術を探る一 21 世紀に向けた変革 一」(1997)

6) 石塚文則, 岩崎 登：「ミリ波回路の実装一端子間接続技 術およびパッケージ技術」, 電気学会研究会資料, 電子デバイ 又研究会 EDD-95-59 (1995)

青木芳雄（あおきよしお）

\section{〔執筆者紹介〕}

1983年, 東北大学大学院 - 理学研究科修了。同年, 富士通秼 入社。以来, GaAsFET, HEMT, MMIC $\sigma$ 開発に従事。 現在，化合物半導体事業部第二技術部。理学博士。 